Jurnal Litbang Vol. XII, No. 2 Desember 2016: 83-92

\title{
FAKTOR-FAKTOR YANG MEMPENGARUHI \\ PRODUKSI IKAN PADA NELAYAN KECIL \\ (Studi di Desa Pecangaan Kabupaten Pati)
}

\section{EFFECTING FACTORS OF FISH PRODUCTION \\ ON SMALL FISHERMAN \\ (Study In Pecangaan village Pati Regency)}

\author{
Herna Octivia Damayanti \\ Kantor Penelitian dan Pengembangan Kabupaten Pati \\ Email: octivia_oc@yahoo.co.id
}

Naskah Masuk: 21 September 2016 Naskah Revisi: 26 September 2016 Naskah Diterima: 5 Oktober 2016

\begin{abstract}
The first fisheries management goal is to improve small fishermen's quality of life. The small fishermen's quality of life depends on the amount of income earned from the fishing activities. The purposes of this research are (1) to analyze the factors that influence the production of the fishermen in Pecangaan Village, (2) to calculate the return to scale of fishermen in Pecangaan Village. This research used descriptive quantitative method and was conducted on August 2016. The research location is in Pecangaan Village, Batangan Subdistrict. It mainly used primary data derived from the respondent (the fisherman in Pecangaan village). Secondary data were derived from the government of Pecangaan Village, Batangan Subdistrict. The number of processed data was 50 samples. The data analysis used Cobb-Douglas production function, in which dependent variable was production quantities and independent variable were: the amount of solar; the number of days at sea; the number of hours at sea; the sailing distance;fishermen's consumption during the sailing, GT boats, number of crew and net's width. The results of the research are (1) the significant factors are the number of days at sea; fishermen's consumption during the sailing, GT boats and net's width. Meanwhile, the insignificant factors are the amount of solar; the number of crew, the sailing distance and the number of hours at sea. (2) The value of return to scale in the production offisherman in Pecangaan Villageis -8.699, means it is in the condition of decreasing return to scale.
\end{abstract}

Keywords : Pecangaan village, Cobb-Douglas function, small fisherman, return to scale

\begin{abstract}
ABSTRAK
Tujuan pengelolaan perikanan yang pertama yaitu untuk meningkatkan taraf hidup nelayan kecil. Taraf hidup nelayan kecil berhubungan dengan jumlah pendapatan yang diperoleh dari hasil tangkapan ikan yang didapat. Tujuan penelitian adalah (1) untuk menganalisis faktor-faktor yang mempengaruhi produksi nelayan Desa Pecangaan, (2) untuk menghitung skala hasil (return to scale) nelayan Desa Pecangaan. Penelitian ini menggunakan metode deskriptif kuantitatif dan dilaksanakan pada bulan Agustus 2016. Lokasi penelitian yaitu di Desa Pecangaan Kecamatan Batangan. Jenis data yang digunakan adalah data primer berasal dari responden (nelayan di Desa Pecangaan). Sedangkan data sekunder berasal dari Pemerintah Desa Pecangaan Kecamatan Batangan. Data yang diolah berjumlah 50 sampel. Analisis data dengan fungsi produksi CobbDouglas, dengan variabel terikat jumlah produksi dan variabel bebas adalah jumlah solar, jumlah hari melaut, lama trip, jarak melaut, konsumsi, GT kapal, jumlah ABK dan luas jaring. Hasil penelitian adalah (1) Faktor yang signifikan yaitu jumlah hari melaut, konsumsi, GT kapal dan luas jaring. Untuk faktor yang tidak signifikan adalah jumlah solar yang digunakan, jumlah ABK, jarak melaut dan lama melaut. (2) Nilai return to scale pada produksi nelayan Desa Pecangaan adalah 8,699 artinya dalam kondisi skala hasil yang menurun (decreasing return to scale).
\end{abstract}

Kata kunci : desa pecangaan, fungsi cobb-douglas, nelayan kecil, skala hasil 
PENDAHULUAN

Walden and Mcguire (2011) menyatakan bahwa perairan laut merupakan sumberdaya alam milik bersama (common property), dimana para nelayan mempunyai hak yang sama untuk memanfaatkan sumberdaya atau melakukan usaha penangkapan ikan.

Sumberdaya ikan termasuk kategori sumberdaya yang dapat diperbaharui (renewable resources), sehingga sering timbul pertanyaan seberapa besar ikan yang dapat dimanfaatkan tanpa harus menimbulkan dampak negatif dimasa mendatang. Menurut Fauzi dan Anna (2005) keberlanjutan merupakan kunci dalam pembangunan perikanan yang diharapkan melalui pengelolaan yang bijaksana dapat memperbaiki kondisi sumberdaya maupun kesejahteraan masyarakat perikanan itu sendiri.

Berdasarkan UU No. 31 Tahun 2004 tentang Perikanan yang diubah dengan UU No.45 Tahun 2009 mengamanatkan bahwa tujuan pengelolaan perikanan adalah untuk (1) meningkatkan taraf hidup nelayan kecil dan pembudidaya ikan kecil; (2) meningkatkan penerimaan dan devisa negara; (3) mendorong perluasan kesempatan kerja; (4) meningkatkan ketersediaan dan konsumsi sumber protein ikan; (5) mengoptimalkan pengelolaan sumber daya ikan; (6) meningkatkan produktivitas, mutu, nilai tambah, dan daya saing; meningkatkan ketersediaan bahan baku untuk industri pengolahan ikan; (8) mengoptimalkan pemanfaatan sumber daya ikan; dan (9) menjamin kelestarian sumber daya ikan, lahan pembudidayaan ikan dan tata ruang. Undang-undang ini memperkuat arah pembangunan nasional untuk berbasis menuju sumber daya kelautan dan perikanan.
Pada tujuan pengelolaan perikanan yang pertama yaitu untuk meningkatkan taraf hidup nelayan kecil. Taraf hidup nelayan kecil berhubungan dengan jumlah pendapatan yang diperoleh dari hasil tangkapan ikan yang didapat. Salah satu wilayah dengan mayoritas penduduknya merupakan nelayan kecil adalah Desa Pecangaan di Kecamatan Batangan Kabupaten Pati. Nelayan Desa Pecangaan menggantungkan hidup dari hasil tangkapan ikan yang didapat per harinya.

Dalam kegiatan penangkapan ikan di laut, terdapat faktor-faktor yang dapat mempengaruhi jumlah tangkapan. Dengan demikian perlu diketahui faktorfaktor yang mempengaruhi produksi nelayan Desa Pecangaan Kabupaten Pati.

Tujuan penelitian ini adalah (1) untuk menganalisis faktor-faktor yang mempengaruhi produksi nelayan Desa Pecangaan, (2) untuk menghitung skala hasil (return to scale) nelayan Desa Pecangaan.

\section{TINJAUAN PUSTAKA}

\section{Fungsi Produksi Cobb-Douglas}

Fungsi produksi Cobb-Douglas diperkenalkan oleh Charles W. Cobb dan Paul H. Douglas. Fungsi produksi ini tercipta setelah melakukan penelitian pada beberapa industri di dunia (Hossain et al, 2013). Fungsi produksi Cobb Douglas adalah hubungan fungsional antara input dan output (Ahmad and Khan, 2015).

Fungsi Cobb-Douglas adalah suatu fungsi yang melibatkan dua atau lebih variabel, yaitu variabel dependen yang dijelasakan atau output (Y) dan variabel independen yang menjelaskan atau input (X) (Soekartawi, 1989). Secara matematis dapat dituliskan sebagai berikut :

$\mathrm{Y}=\mathrm{aX}_{1}{ }^{\mathrm{b} 1} \mathrm{X}_{2}^{\mathrm{b} 2} \ldots \mathrm{X}_{\mathrm{n}}^{\mathrm{bn}} \mathrm{e}^{\mathrm{u}}$.

Keterangan ; 
Y : variabel yang dijelaskan (output)

$\mathrm{X}$ : variabel yang menjelaskan (input)

a,b : besaran yang akan diduga

$\mathrm{u}$ : kesalahan (disturbance term)

e : logaritma natural, e $=2,178$

Mahdiana dalam Picaulima, 2012 menyatakan, untuk menaksir variabelvariabel harus ditransformasikan dalam bentuk double logaritme natural (ln) sehingga merupakan bentuk linear berganda (multiple linear) yang kemudian dianalisis dengan metode kuadrat terkecil (Ordinary Least Square). Persamaan fungsi produksi CobbDouglas :

Ln $\mathrm{Y}=\operatorname{Ln} \mathrm{A}+\mathrm{b}_{1} \operatorname{LnX}_{1}+\mathrm{b}_{2} \operatorname{LnX}_{2}+\ldots$ $b_{n} \operatorname{LnX}_{n}+\mu$

\section{Nelayan}

UU No. 45 Tahun 2009 menyebutkan bahwa nelayan adalah orang yang mata pencahariannya melakukan penangkapan ikan. Menurut Kusnadi (2009), Secara geografis, masyarakat nelayan adalah masyarakat yang hidup, tumbuh, dan berkembang di kawasan pesisir, yakni suatu kawasan transisi antara wilayah darat dan wilayah laut. Sebagai suatu sistem, masyarakat nelayan terdiri atas kategori-kategori sosial yang membentuk kekuatan sosial. Mereka juga memiliki sistem nilai dan simbol-simbol kebudayaan sebagai referensi perilaku mereka sehari-hari. Faktor budaya ini menjadi pembeda masyarakat nelayan dari kelompok masyarakat lainnya. Sebagian besar masyarakat pesisir, baik langsung maupun tidak langsung menggantungkan kelangsungan hidupnya dari mengelola potensi sumberdaya perikanan. Mereka menjadi komponen utama konstruksi masyarakat maritim Indonesia.

\section{Nelayan Kecil}

Nelayan kecil addalah orang yang mata pencahariannya melakukan penangkapan ikan untuk memenuhi kebutuhan hidup sehari-hari yang menggunakan kapal perikanan berukuran paling besar 5 (lima) gross ton (GT) (UU No. 45 Tahun 2009). Menurut Retnowati (2011), nelayan kecil pada dasarnya berasal dari nelayan tradisional hanya saja dengan adanya program modernisasi/motorisasi perahu dan alat tangkap maka mereka tidak lagi sematamata mengandalkan perahu tradisional maupun alat tangkap yang konvensional saja melainkan juga menggunakan diesel atau motor, sehingga jangkauan wilayah penangkapan agak meluas atau jauh.

\section{METODE PENELITIAN}

Penelitian ini menggunakan metode deskriptif kuantitatif dan dilaksanakan pada bulan Agustus 2016. Lokasi penelitian yaitu di Desa Pecangaan Kecamatan Batangan. Jenis data yang digunakan dalam penelitian ini adalah data primer dan data sekunder. Data primer berasal dari responden (nelayan di Desa Pecangaan). Teknik pengumpulan data dengan cara wawancara dengan bantuan kuesioner. Wawancara digunakan untuk mengumpulkan data primer yaitu dengan melakukan wawancara langsung terhadap responden berdasarkan daftar pertanyaan (kuesioner) yang telah dipersiapkan sebelumnya. Sedangkan data sekunder berasal dari Pemerintah Desa Pecangaan Kecamatan Batangan. Sampel penelitian diambil berdasarkan jumlah populasi nelayan yang ada di Desa Pecangaan Kecamatan Batangan. Dalam pengambilan sampel ditetapkan beberapa kriteria yaitu : 
Tabel 1.

Kriteria Sampel Penelitian

\begin{tabular}{cl}
\hline No. & \multicolumn{1}{c}{ Kriteria } \\
\hline 1. & Bermata pencaharian sebagai nelayan \\
2. & Nelayan pemilik kapal \\
3. & Bertempat tinggal di Desa Pecangaan \\
4. & Pengalaman menjadi nelayan $\geq 5$ tahun \\
5. & Kapal yang dioperasikan bermesin 5-10 GT \\
\hline
\end{tabular}

Jumlah populasi penduduk yang bermata pencaharian sebagai nelayan di Desa Pecangaan Kecamatan Batangan adalah 274 orang dengan rincian 190 orang merupakan nelayan pemilik kapal bermesin 5-10 GT, 5 orang merupakan nelayan pemilik kapal bermesin < 5 GT dan 79 orang merupakan ABK (Anak Buah Kapal) (Pecangaan, 2015). Berdasarkan data tersebut maka jumlah nelayan yang sesuai dengan kriteria pada Tabel 1 yaitu 190 orang. Jika mengacu pada Monogram Harry King pada tingkat kesalahan 5\% maka diperoleh jumlah sampel sebanyak 55 orang.

Setelah dilakukan rekapitulasi data diketahui bahwa range data produksi adalah $1 \mathrm{~kg}$ sampai $40 \mathrm{~kg}$. Untuk meminimalisir terjadinya heterokesdatisitas, maka data yang digunakan dibatasi menjadi $1-10 \mathrm{~kg}$. Pertimbangan yang diambil saat menentukan batasan adalah pemenuhan kebutuhan data untuk pengolahan data selanjutnya. Dengan demikian, data yang diolah berjumlah 50 sampel karena terdapat 5 data outlier.

Analisis data dengan fungsi produksi Cobb-Douglas. Fungsi produksi Cobb-Douglas dipilih sebagai bentuk hubungan antara jumlah produksi dengan variabel bebasnya. Produksi nelayan di Desa Pecangaan Kecamatan Batangan Kabupaten Pati merupakan fungsi dari : jumlah produksi, jumlah solar, jumlah hari melaut, lama trip, jarak melaut, konsumsi, GT kapal, jumlah ABK dan luas jaring.

Tabel 2.

Variabel Terikat dan Tidak Terikat Produksi Nelayan Kecil Desa Pecangaan

\begin{tabular}{llcc}
\hline No & Nama Variabel & Keterangan & $\begin{array}{c}\text { Skala } \\
\text { Pengukuran }\end{array}$ \\
\hline 1 & Produksi nelayan & Ln Y & $\mathrm{kg}$ \\
& Pecangaan & Lnsolar & liter \\
2 & Jumlah solar & Lnhari & hari \\
3 & Jumlah hari melaut & Lnlama & jam \\
4 & Lama trip & Lnjarak & mil \\
5 & Jarak melaut & Lnkonsumsi & Rupiah \\
6 & Konsumsi & LnGT & GT \\
7 & GT kapal & LnABK & Orang \\
8 & Jumlah ABK & Lnjaring & $\mathrm{m}^{2}$ \\
9 & Luas jaring & & \\
\hline
\end{tabular}


Secara matematis persamaan tersebut dapat ditulis sebagai berikut :

$Y$

$=f($ Solar, Hari, Lama, jarak, konsumsi, $G T, A B K$, jaring)

Bentuk Estimasi fungsi produksi

Cobb-Douglas adalah sebagai berikut :

Ln $\mathrm{Y}=$

Ln $b+b_{1}$ Lnsolar $+b_{2}$ Lnhari $+b_{3}$

Lnlama $+b_{4}$ Lnjarak $+b_{5}$ Lnkonsumsi

$+b_{6}$ LnGT $+b_{7}$ LnABK $+b_{8}$ Lnjaring

Return to scale untuk produksi

nelayan Desa Pecangaan dihitung dari penjumlahan koefisien elastisitas input fisik yaitu Lnsolar, Lnhari, Lnlama, Lnjarak, LnGT, LnABK dan Lnjaring. Secara sistematis dirumuskan sebagai berikut :

$\sum b_{i}$ fisik $=b_{1}+b_{2}+b_{3}+b_{4}+b_{5}+b_{6}+b_{7}$
Keterangan :

$\mathrm{b}_{1}=$ koefisien elastisitas Lnsolar

$\mathrm{b}_{2}=$ koefisien elastisitas Lnhari

$\mathrm{b}_{3}=$ koefisien elastisitas Lnlama

$\mathrm{b}_{4}=$ koefisien elastisitas Lnjarak

$\mathrm{b}_{5}=$ koefisien elastisitas LnGT

$\mathrm{b}_{6}=$ koefisien elastisitas LnABK

$\mathrm{b}_{7}=$ koefisien elastisitas Lnjaring

HASIL DAN PEMBAHASAN

\section{Faktor Produksi Nelayan Desa}

Pecangaan

Faktor produksi nelayan Desa Pecangaan yaitu jumlah produksi, jumlah solar, jumlah hari melaut, lama trip, jarak melaut, konsumsi, GT kapal, jumlah ABK dan luas jaring. Profil produksi nelayan Desa Pecangaan disajikan pada Tabel 4.

Tabel 4.

Profil Faktor Produksi Nelayan Desa Pecangaan

\begin{tabular}{lcrrrr}
\hline \multicolumn{1}{c}{ Variabel } & satuan & Minimum & \multicolumn{1}{c}{ Maksimum } & \multicolumn{1}{c}{ Mean } & Std. Deviation \\
\hline Produksi & $\mathrm{kg}$ & 1 & 10 & 4,380 & 1,915 \\
Solar & liter & 60 & 520 & 271,880 & 126,055 \\
Hari melaut & hari & 20 & 30 & 24,700 & 1,854 \\
Lama melaut & jam & 4 & 10 & 7,120 & 1,223 \\
Jarak melaut & mil & 3,108 & 9,323 & 6,439 & 2,051 \\
konsumsi & Rp & 140.000 & 1.560 .000 & 584.000 & $331.868,354$ \\
GT kapal & GT & 5 & 10 & 5,440 & 1,248 \\
Jumlah ABK & orang & 1 & 3 & 2,040 & 0,402 \\
Luas jaring & $\mathrm{m}^{2}$ & 72 & 75 & 74,753 & 0,698 \\
\hline
\end{tabular}

Sumber data: Pengolahan Data (2016)

Produksi minimum nelayan Desa Pecangaan adalah $1 \mathrm{~kg}$, produksi maksimum $40 \mathrm{~kg}$, produksi rata-rata $6,620 \mathrm{~kg}$ dan standar deviasi 7,644 kg. Jumlah solar minimum yang digunakan adalah 60 liter, solar maksimum 780 liter, solar rata-rata 299,160 liter dan standar deviasi 159,705 liter. Untuk faktor produksi jumlah hari melaut, jumlah hari melaut minimum 20 hari, jumlah hari melaut maksimum 30 hari, jumlah hari melaut rata-rata 24,820 hari dan standar deviasi 1,806 hari.

Faktor produksi lama melaut, minimum adalah 4 jam, maksimum 10 jam, rata-rata adalah 7,180 jam dan standar deviasi adalah 1,249 jam. Untuk faktor produksi jarak melaut minimum 
adalah 3,108 mil, jarak melaut maksimum adalah 12,430 mil, jarak melaut rata-rata adalah 6,554 mil dan standar deviasi adalah 2,119 mil.

Faktor produksi konsumsi, minimum adalah Rp. 140.000,- dan maksimum Rp. 1.560.000,-. Rata-rata konsumsi adalah Rp. 584.000,- dan standar deviasi Rp. 331.868,354. Untuk faktor produksi GT kapal, GT kapal minimum adalah 5 GT, GT maksimum adalah $10 \mathrm{GT}$, GT rata-rata adalah 5,44 GT dan standar deviasi 1,248 GT.

Faktor produksi jumlah ABK minimum adalah 1 orang dan maksimum adalah 3 orang. Rata-rata jumlah ABK 2,04 orang dan standar deviasi 0,402 orang. Untuk faktor produksi luas jaring, minimum adalah $72 \mathrm{~m}^{2}$ dan maksimum adalah $75 \mathrm{~m}^{2}$. Luas jaring rata-rata adalah $74,753 \mathrm{~m}^{2}$ dan standar deviasi $0,698 \mathrm{~m}^{2}$.

\section{Fungsi Produksi Nelayan Desa Pecangaan}

Hasil estimasi fungsi produksi Cobb-Douglas untuk produksi nelayan Desa Pecangaan terdapat input yang signifikan (Sig. < 0,05) yaitu input Lnhari (Sig. 0,002), Lnkonsumsi (Sig. 0,031), LnGT (Sig. 0,018) dan Lnjaring (Sig. 0,031). Untuk variabel yang tidak signifikan adalah input Lnsolar (Sig. 0,125), LnABK (Sig. 0,992), Lnjarak (Sig. 0,897) dan Lnlama (Sig. 0,100). Hasil estimasi secara lengkap disajikan pada Tabel 5. Estimasi fungsi produksi Cobb-Douglas untuk produksi nelayan Desa Pecangaan :

Ln Produksi =

Ln 43,527 - 0,230 Lnsolar +

2,709 Lnhari + 0,311 Lnkonsumsi +

0,742 LnGT + 0,003 LnABK+

0,024 Lnjarak + 0,527 Lnlama12,474 Lnjaring

Koefisien variabel input pada fungsi produksi Cobb-Douglas untuk produksi nelayan Desa Pecangaan bernilai positif dan negatif menunjukkan bahwa model tidak dalam kondisi normal yaitu terjadi kecenderungan fungsi produksi sudah jenuh dan cenderung mengalami penurunan produksi.

Uji keterandalan model atau uji kelayakan model atau yang lebih populer disebut sebagai uji F merupakan tahapan awal mengidentifikasi model regresi yang diestimasi layak atau tidak. Layak yang dimaksud adalah model yang diestimasi layak digunakan untuk menjelaskan pengaruh variabel-variabel independent terhadap variabel dependent (Iqbal, 2015). Hasil perhitungan menunjukkan bahwa nilai probabilitas $\mathrm{F}$ hitung adalah 0,000 sehingga dapat dikatakan bahwa model regresi yang diestimasi layak karena nilai probabilitas $<0,05$.

Iqbal (2015) menyebutkan bahwa koefisien determinasi menjelaskan variasi pengaruh variabel-variabel independent terhadap variabel dependent atau dapat pula dikatakan sebagai proporsi pengaruh seluruh variabel independent terhadap variabel dependent. Nilai koefisien determinasi dapat diukur oleh nilai R-Square. Pada hasil perhitungan diperoleh bahwa nilai RSquare adalah 0,527. Hal ini menunjukkan bahwa proporsi pengaruh antar variabel independent sebesar 52,7\%. Dengan demikian, sebesar 47,3\% produksi nelayan Desa Pecangaan dipengaruhi oleh faktor lain diluar jumlah solar yang digunakan, jumlah hari melaut, konsumsi, GT kapal, jumlah ABK, jarak melaut, lama melaut dan luas jaring. Faktor lain yang mungkin berpengaruh adalah faktor perubahan musim dan iklim.

Diposaptono dalam Putra (2013) menyatakan bahwa lautan amat terkait dengan perubahan iklim, yang dicirikan dengan adanya perubahan suhu yang semakin naik, hidrologi, pola angin, dan 
kenaikan paras muka air laut. Selain itu pola hujan juga berubah, dimana musim hujan semakin pendek, tetapi curah hujannya tinggi.

Perubahan iklim menurut UU No. 31 Tahun 2009 adalah berubahnya iklim yang diakibatkan langsung atau tidak langsung oleh aktivitas manusia yang menyebabkan perubahan komposisi atmosfer secara global serta perubahan variabilitas iklim alamiah yang teramati pada kurun waktu yang dibandingkan. Pada tahun 2015 saat dilakukan penelitian sedang terjadi fenomena El Nino. Berdasarkan pernyataan Syahailatua (2008), El Nino atau Southern Oscillation (ENSO) merupakan fenomena alam yang mengakibatkan fluktuasi suhu permukaan air laut dan kenaikan muka air laut, sehingga menyebabkan penurunan produksi perikanan laut.

Tabel 5.

Estimasi Fungsi Cobb-Douglas Untuk Produksi Nelayan Desa Pecangaan

\begin{tabular}{lrrr}
\hline \multicolumn{1}{c}{ Variabel } & Koefisien & t-hitung & Sig. \\
\hline (Constant) & 43,527 & 24,538 & 0,084 \\
Lnsolar & $-0,230$ & 0,147 & 0,125 \\
Lnhari & 2,709 & 0,841 & 0,002 \\
Lnkonsumsi & 0,311 & 0,139 & 0,031 \\
LnGT & 0,742 & 0,301 & 0,018 \\
LnABK & 0,003 & 0,249 & 0,992 \\
Lnjarak & 0,024 & 0,185 & 0,897 \\
Lnlama & 0,527 & 0,313 & 0,100 \\
Lnjaring & $-12,474$ & 5,599 & 0,031 \\
\hline R-square & & 0,527 \\
F hitung & & 5,701 \\
Sig. F hitung & & 0,000 \\
Return to scale & & & $-8,699$ \\
N & & & 50 \\
\hline Deteksi Multikolinearitas & & data cross-section \\
- Tolerance & dapat diterima \\
- VIF & & $<0,10$ \\
- Zero-order, partial, part & & $<10$ \\
- Matriks koefisien korelasi & & $<0,8$ \\
Kesimpulan & & tdk ada autukorelasi \\
\hline Deteksi Heteroskedastisitas & &
\end{tabular}

Sumber data: Pengolahan Data (2016)

\section{Return To Scale (Skala Hasil) Produksi Nelayan Desa Pecangaan}

Nilai return to scale pada produksi nelayan Desa Pecangaan adalah $\sum$ bi fisik $=-0,230+2,709+0,742$

$$
\begin{aligned}
& +0,003+0,024 \\
& +0,527-12,474 \\
& =-8,699
\end{aligned}
$$

Hasil penjumlahan tersebut menjelaskan bahwa produksi nelayan Desa Pecangaan berada dalam kondisi skala hasil yang menurun (decreasing return to scale), karena nilai return to scale kurang dari 1. Hal ini diduga disebabkan karena terjadi over eksploitasi terhadap sumberdaya ikan di 
wilayah penangkapan dan pengaruh perubahan iklim.

\section{Fungsi Produksi Perikanan}

Fungsi produksi perikanan jangka pendek adalah hubungan antara tangkapan (catch) dan upaya (effort), sedangkan dalam jangka panjang merupakan hubungan antara penangkapan dan rata-rata penangkapan yang dapat diperoleh pada waktu tertentu tanpa mempengaruhi stok ikan (Anderson, 1986). Susilowati (2006) menyebutkan bahwa menurut teori produksi, terdapat 4 tahapan produksi sumberdaya alam dilihat dari jumlah penggunaan input. Tahap I, produksi yang dapat mencapai keuntungan ekonomi yang maksimum (Maximum Economic Yield/MEY) yaitu dapat dikatakan sumberdaya tersebut masih dalam tahap kejayaan secara ekonomis, karena dapat memberikan tambahan hasil yang semakin meningkat dengan bertambahnya input produksi.

Tahap II, produksi yangdapat mencapai jumlah produksi fisik yang maksimum (Maximum Sustainable Yield/MSY) yaitu semakin banyak penggunaan input maka sumberdaya ini akan memberikan hasil yang semakin berkurang. Tahap III, produksi yang tidak memperoleh untung atau rugi (break even point atau open acsess). Tahap IV, produksi yang merugi. Jika produksi mulai masuk pada tahap III dan IV, akan mengalami hukum berkurangnya hasil (law of diminishing return) bila ditambahkan input produksi, perilaku produksi tersebut terjadi pada semua sumberdaya alam termasuk perikanan. Hubungan antara MEY, MSY dan Open Access Equilibrium (OAE) ditunjukkan pada Gambar 2.

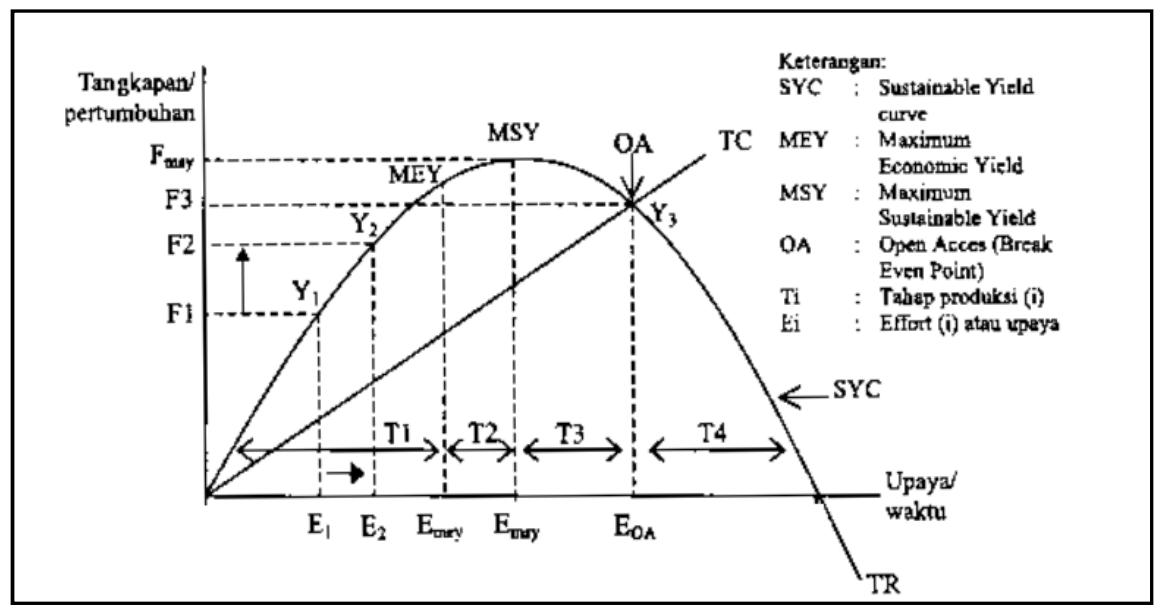

Gambar 1.

Hubungan antara MEY, MSY dan OAE (Susilowati, 2006)

Produksi nelayan Desa Pecangaan, berada pada rentang tahap II akhir dan tahap III atau transisi tahap II ke tahap III atau mulai terjadi penurunan produksi. Hal ini ditandai dengan koefisien input produksi yang bernilai positif dan negatif. Koefisien input produksi terlihat saling bertolak belakang, misalnya koefisien input solar bernilai negatif dan koefisien input jumlah hari melaut bernilai positif. Jika pada kondisi Tahap I, kedua input produksi tersebut akan bernilai positif atau berbanding lurus. 


\section{KESIMPULAN DAN SARAN}

\section{Kesimpulan}

1).Faktor yang signifikan yaitu jumlah hari melaut, konsumsi, GT kapal dan luas jaring. Untuk faktor yang tidak signifikan adalah jumlah solar yang digunakan, jumlah ABK, jarak melaut dan lama melaut.

2).Nilai return to scale pada produksi nelayan Desa Pecangaan adalah 8,699 artinya dalam kondisi skala hasil yang menurun (decreasing return to scale).

\section{Saran}

1).Perlu dibuat peraturan (dapat berupa Perda) untuk mengendalikan dan membatasi upaya penangkapan. Pembatasan kuota atau jumlah tangkapan juga dilakukan agar jumlah tangkapan tidak melampaui TAC sehingga pengelolaan sumberdaya ikan laut dapat dilakukan secara berkelanjutan.

2).Perlu adanya sosialisasi tentang perubahan iklim dan efek dari perubahan iklim terhadap kelautan dan perikanan sehingga nelayan diharapkan dapat melakukan proses adaptasi.

\section{DAFTAR PUSTAKA}

Ahmad, A. and M. Khan. 2015. Estimating The Cobb-Douglas Production Function. International Journal of Research in Business Studies and Management, Vol 2 (5) : 32-33.

Anderson, L. G. 1986. The Economic of Fisheries Management. The John Hopkins University, USA.

Badan Pusat Statistik Kabupaten Pati. 2014. Kecamatan Batangan Dalam Angka Tahun 2013. Pati.
Fauzi, A. Dan S. Anna. 2005. Pemodelan Sumberdaya Perikanan dan Kelautan. PT. Gramedia Pustaka Utama. Jakarta.

Hossain, Md. M., T. Basak and A. K. Majumder. 2013. Application of Non-Linear Cobb-Douglas Production Function With Autocorrelation Problem to Selected Manufacturing Industries in Bangladesh. Open Journal of Statistics, Vol 3 : 173-178.

Iqbal, M. 2015. Pengolahan Data Dengan Regresi Linier Berganda (Dengan SPSS). Jakarta : Perbanas Institute Jakarta.

Kusnadi. 2009. Keberdayaan Nelayan Dan Dinamika Ekonomi Pesisir. Pusat Penelitian Wilayah Pesisir Dan Pulau-Pulau Kecil. Lembaga Penelitian Universitas Jember, Jember.

Pecangaan. 2015. Rekapitulasi Data Nelayan Desa Pecangaan. Pati.

Picaulima, S. M. 2012. Analisis Pengaruh Faktor Produksi Terhadap Produktivitas Perikanan Pukat Cincin Di Kabupaten Maluku Tenggara. Journal of Tropical Fisheries, Vol 7(1) : 611616.

Putra, S. E. 2013. Analisis Usaha Penangkapan Ikan Yang Berkelanjutan Pada Kondisi Perubahan Iklim. Tesis. Program Studi Magister Ilmu ekonomi Studi Pembangunan. Universitas Diponegoro, Semarang.

Retnowati, E., 2011. Nelayan Indonesia Dalam Pusaran Kemiskinan Struktural (Persspektif Sosial, ekonomi Dan Hukum). Perspektif, Vol XVI (3) : 149-159. 
Soekartawi 1989. Prinsip Dasar Ekonomi Pertanian : Teori dan Aplikasi. CV. Rajawali, Jakarta.

Sudantoko, D. 2010. Pemberdayaan Industri Batik Skala Kecil di Jawa Tengah. Disertasi. Program Pasca Sarjana. Universitas Diponegoro, Semarang.

Susilowati, I . 2006. Keselarasan Dalam Pemanfaatan Dan Pengelolaan Sumberdaya Perikanan Bagi Manusia dan Lingkungan. Pidato Pengukuhan Guru Besar Fakultas Ekonomi Universitas Diponegoro, Semarang.

Syahailatua, A. 2008. Dampak Perubahan Iklim Terhadap Perikanan. Jurnal Oseana, Vol XXXIII (2) : 25-32.

Undang-undang Republik Indonesia Nomor 31 Tahun 2009 Tentang Meteorologi, Klimatologi, dan Geofisika.
Undang-Undang Republik Indonesia Nomor 45 Tahun 2009 Tentang Perikanan.

Walden, J. B. and C. J. McGuire. 2011. Who Owns The Fish? Moving From The Commons To Federal Ownership Of Our National Fisheries. Marine Resources Committee Newsletter, Vol. 14 (2) : 3-7.

\section{BIODATA PENULIS}

Herna Octivia Damayanti, lahir 6 Oktober 1985 di Kudus Jawa Tengah. Pendidikan Magister Manajemen Sumberdaya Pantai Universitas Diponegoro tahun 2016. Saat ini bekerja sebagai Peneliti di Kantor Penelitian dan Pengembangan Kabupaten Pati. 